\title{
Geochemical Evidence for the Origin of the Daranna Manganese Deposit, Kebbi State, Nigeria
}

\author{
${ }^{* 1}$ L. M. Adamu, ${ }^{2}$ N. G. Obaje, ${ }^{3}$ A. A. Sidi, ${ }^{3}$ A, K. Aweda, ${ }^{4}$ H. M. Liman \\ ${ }^{1}$ Department of Earth Sciences, Kogi State University, Anyigba, Nigeria \\ ${ }^{2}$ Nigerian National Petroleum Corporation Chair in Basinal Studies, Ibrahim Badamasi Babangida University, Lapai, Nigeria \\ ${ }^{3}$ Department of Geology, Ibrahim Badamasi Babangida University Lapai, Nigeria \\ ${ }^{4}$ Department of Geography, Ibrahim Badamasi Babangida University Lapai, Nigeria
} [ ${ }^{*}$ Corresponding Author: E-mail: lukman10musa@yahoo.com]

\begin{abstract}
Inorganic and organic geochemical and geostatistical studies of manganese ore deposits exposed at Daranna, near Kaoje have been carried out with the aim of characterizing and delineating the origin of the manganese ore deposits. Data were obtained from field observations and chemical analyses of 12 ore samples. Major and trace elements and organic geochemical analyses were conducted with Energy Dispersion X-ray Fluorescence Spectrometer and Rock-Eval pyrolysis method at Geo-data GmbH Garbsen, Germany. Results of the Major and trace elements, total organic carbon content abundances and the correlation among them imply that Daranna mineralizations are mainly of hydrothermal origin with little contribution from contemporaneous volcanic materials and this is confirmed by high Fe/Mn (8.274 to 24.066 wt $\%$ ) and low Co/Zn ratios and trace element patterns. The significant geochemical characteristics such as high Mn content (22.660 to 62.330 wt\%; average 45.919 wt\%), low concentration of Fe (2.590 to 3.310 wt\%; average $3.008 \mathrm{wt} \%$ ) reveal a primary distal hydrothermal source for mineralization. The position of samples on $\mathrm{Ni}-\mathrm{Zn}-\mathrm{Co}$ and $(\mathrm{Co} / \mathrm{Zn})-(\mathrm{Co}+\mathrm{Ni}+\mathrm{Cu})$ diagrams and evaluation of these data reveals that hydrothermal activity was the main process with sedimentary influence responsible for mineralization in the Daranna manganese deposit.
\end{abstract}

Keywords: Daranna, Manganese, Trace Element, Major Element, Hydrothermal, Geochemistry

\section{INTRODUCTION}

The $923,768 \mathrm{~km}^{2}$ extent area Nigeria is covered in just about uniform ratio by basement and sedimentary rocks terrain (Obaje, 2009). Workers like Odeyemi (1977), Ajibade et al. (1987), Caby (1989) reported that the Nigerian Basement Complex is characterized by different grades of metamorphism, orogenies and structural modifications which have been reflected in its complex petrological, structural composition and mineralization potential. Woakes et al. (1987), Dada et al. (1989), Oyinloye (2006) in their work discussed the younger metasediments in Nigeria to be well known for their mineralization such as Gold, Banded Iron Formation (BIF), lead/zinc ores, tantalite manganese deposits and marble.

Raw Material Research and Development Councils -RMRDC, (2009) reported over $5,000,000$ metric tons (MT) of manganese deposit in Nigeria. Manganese are normally developed as a mineral in the form of silicates, carbonates or oxides of which their origin are hitched to a great many factors: a-few of which are in a scope of tectonic frameworks, with ore deposits being linked with ophiolites as well as continental sedimentary sequences, depositional environment, climate and biogenic conditions (Polgári et al., 2012; Öksüz, 2011; Hein et al., 1997; Bolton et al.,1988). These deposits can be divided into three types based on mineralogy, geochemical composition and tectonic setting: (1) hydrogenous, (2) hydrothermal, and (3) diagenetic/biogenetic-bacterial deposits.

The manganese deposits in this study are located in Daranna village which is situated near Kaoje of Kebbi State (Figure 1). The area lies within the geographical coordinates: $11011^{\prime} \mathrm{N}$ and $4{ }^{\circ} 7^{\prime} \mathrm{E}$. This Daranna manganese occurrence was first 


\section{Nigerian Journal of Basic and Applied Science (December, 2021), 29(2):30-45}

reported by this research based on a tip off by local communities. The study noted that the locality is at the boundary between the Basement Complex and sedimentary rocks of the Sokoto Basin (Figure 1). The Manganese deposits were actually not too distant from an outcropping basement granite-gneiss to the north-west of the deposit but no other rock exposures were mapped again in the vicinity of the manganese deposit to enable a proper deciphering of its modes of occurrence. The Daranna manganese is dark and appears like coal but has more weight when compared with coal (Figure 2). It is being commercially mined by local miners since the deposit is large.

Several works have reported the occurrence of manganese in the northwestern part of Nigeria. Earlier documentation on manganese mineralization appeared in the works of Truswell and Cope (1963), Wright and McCurry (1970), Bar and Mucke (1982), Moneme and Scott (1983), Moneme et al. (1982), Mucke and Okujeni (1984), Raeburn (1927) and Bafor and Mucke (1990), Yaro, (1998), Raw Material Research and Development Councils -RMRDC (2009), National Steel Raw Materials Exploration Agency NSRMEA (2010), Mucke (2005), Muriana et al. (2014) and Muriana (2016). Truswell and Cope, (1963) in their work identified pelitic and semi pelitic rocks, banded iron rocks, amphibolites and other minor rocks, like magnesian rich (talcose rock) and schistose varieties in the Basement Complex. Wright and McCurry, (1970) in their work on the manganese deposits at Mallam Ayuba within the Maru schist belt observed that the manganese mineralization occurs in ridges for over $800 \mathrm{~m}$ along a north- south strike and lying near Mallam Ayuba settlement. Bar and Mucke (1982) reported that the ore bodies composed of massives brown- gray-black, jointed or fractured, fine-grained iron manganese mineralization dipping at 850 east with strike direction of 1100 , having according to Moneme and Scott (1983) a conformable beds of quartzite that contains banded iron formation (BIF), gold and amphibolites.

Moneme et al. (1982), Mucke and Okujeni (1984) worked on the Tudun Kudu manganiferous ore and reported that the ore occur within Precambrian Karaukarau schist belt. They according to Moneme et al. (1982), Mucke and Okujeni (1984) are Proterozoic rocks, folded into synclinorial belts within the crystalline Basement Complex, and metamorphosed to phyllites, quartzites and psammitic schists of low to medium grade. Raeburn (1927) and Bafor and Mucke (1990) in their studies reported small quantities of manganese deposits from Basement rocks in South-eastern and South-western parts of Nigeria (Figure 1). However, they reported that the mineralizations are mostly of poor grade, and thus require some processing to improve quality for industrial uses.

Studies by Yaro, (1998) and Binta et al., (2016) were aimed at upgrading of the manganese ore. These authors worked on decolourization of manganese ore from Maikujeri and Kaoje area using magnetic separation and acid bleaching as route for beneficiation. Binta, (2013) assessed the manganese concentrates in the area with emphasis on its industrial application. Yaro (1996), Binta (2013), Muriana et al. (2014), Muriana, (2016) and Binta et al. (2016) worked on the beneficiation of Nigeria manganese ores. The investigation carried out by Yaro, (1996) and Muriana et al. (2014) concentrated on appraisal of manganese deposits in the study areas with emphasis on its metallurgical features. Muriana, (2016) affirmed the hydrometallurgical extraction of manganese metal by thermal decomposition of the purified manganous nitrate $\left(\mathrm{MnN}_{2} \mathrm{O}_{6}\right)$ crystals to synthesize the chemical manganese dioxide (CMD) from Madaka area. 


\section{Adamu et al: Geochemical Evidence for the Origin of the Daranna Manganese Deposit...}

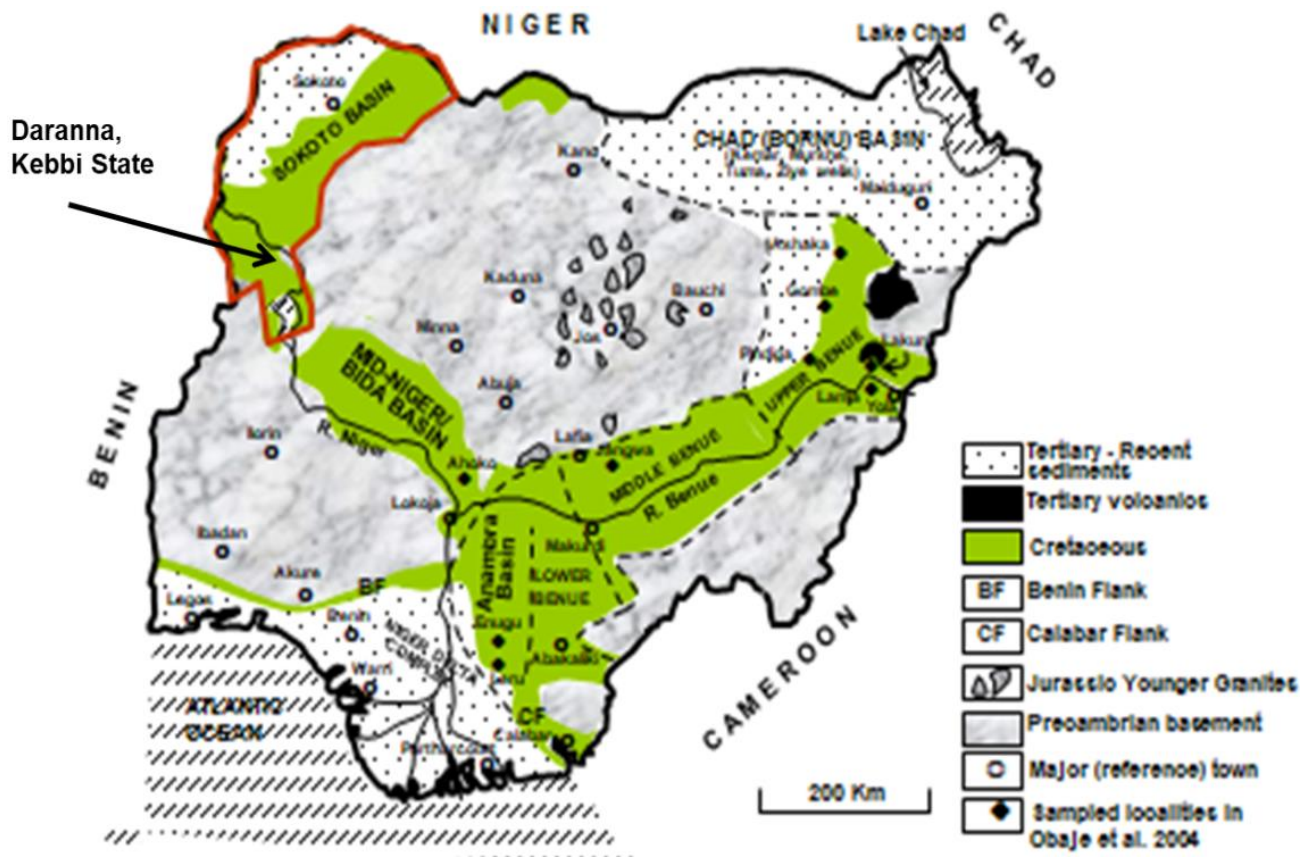

Figure. 1. Generalized geological map of Nigeria showing location of Daranna within the Sokoto Basin (After Obaje, 2009).

The works of Mücke et al. (1999) Mücke (2005), Yaro (1998) and Binta (2013) whose attention channeled to the Banded iron formations (BIFs) which are found to intersperse with manganese ores in the study areas report the association between BIFs and manganese in area around Maru. Mucke (2005) reported that vast majority of manganese deposits are of sedimentary character and emphasized on the importance of additional processes as critical in the development of large accumulation of manganiferrous sediments in depositional environment. Available results of geological studies show that in Nigerian, most of the manganese deposits are found in the schist belts in the Basement Complex and are of metamorphic origin (Mucke and Okujeni, 1984). Therefore, this research was conducted with the aim of determining the geochemical compositions and Petrogenetic characterization of the manganese deposits around Daranna area. Hence, it documents the first geochemical study of the ore deposits in the study area which include descriptions and identification of the deposits in-situ exposures. The study also disclosed the elemental composition of the manganese as well as the organic contents. The findings of this work would help in the understanding of the origin of the Daranna manganese deposits in the study area.

\section{MATERIALS AND METHODS}

Twelve ore samples (300 g each) were systematically collected from the field using grid sampling technique from the Daranna manganese deposit using the materials such as hammer, shovel, sample bags, marker and global positioning system (GPS) (Figure 2) 


\section{Nigerian Journal of Basic and Applied Science (December, 2021), 29(2):30-45}

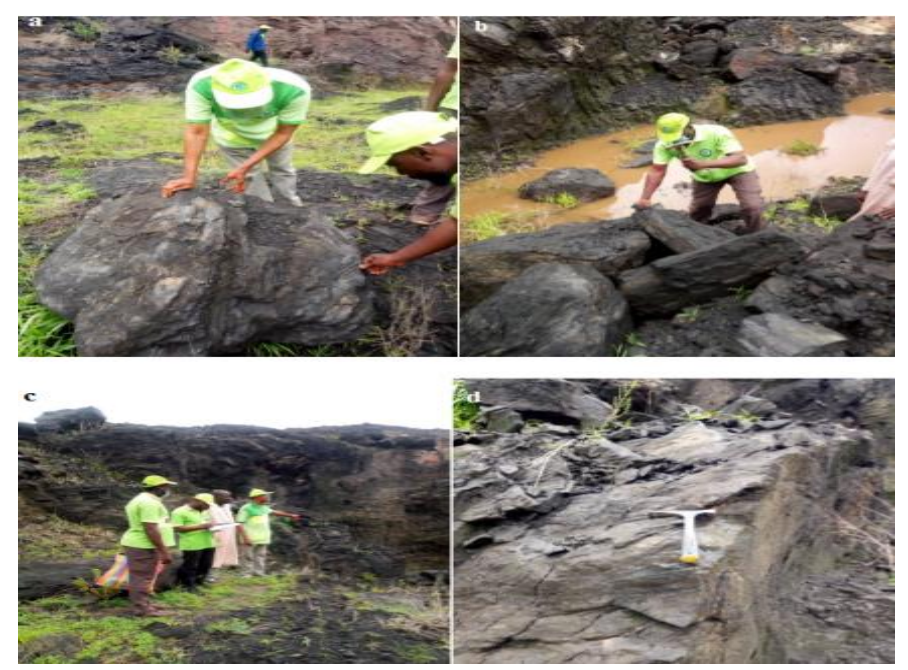

Figure 2. Field photographs of massive manganese deposit at N11006'51.7' and E00400' $25.1^{\prime \prime}$ in Daranna, $(a, b, c \& d)$ shows authors doing a macro examination of the deposits insitu.

\section{Geochemical Methods of Analysis}

The Geochemical analysis involved taking the selected samples firstly to the sample preparation laboratory for pulverization in IBBU Lapai CASTER Laboratory, Nigeria. The pulverizing machine ground or milled the rock sample into fine grain form with crystals not more than $60 \mu \mathrm{m}$. The pulverized sample was measured and further made into pellets using deionized water. The pellet was then air-dried and introduced into the vacuum chamber of Energy Dispersion X-ray Fluorescence Spectrometer machine and analyzed following the standard procedures (Norrish and Hutton, 1969) at Geo-data $\mathrm{GmbH}$ Garbsen, Germany. Major oxide and trace element contents were determined. In addition, in order to strengthen the inorganic geochemical results, six (6) selected manganese field samples from Daranna of the northwestern Kebbi, Nigeria (Table 1) were analyzed for total organic carbon(TOC) using LECO carbon analyzer, and Rock-Eval pyrolysis. The LECO TOC content and Rock-Eval pyrolysis analyses were made in the laboratory of Geo-data GmbH Garbsen, Germany. The Analyses were performed on 80 $\mathrm{mg}$ to $102 \mathrm{mg}$ crushed whole rock samples, heated to $600{ }^{\circ} \mathrm{C}$ in a helium atmosphere, using a LECO and Rock-Eval 6 unit.

\section{Geostatistical Analysis of Daranna Manganese Deposit}

Multivariate statistical analysis was applied to probe on the relationship between organic and inorganic geochemical study and their instrumentality to unravelling the origin of the Daranna manganese deposit. The results (XRF, LECO and Rock Eval Pyrolysis) obtained for studied samples were statistically analyzed using cluster analysis hierarchical and K-means cluster analysis) and Pearson's correlation by SPSS 15.0 (Zhang et al., 2007). Cluster analysis is based on a matrix measuring the differences between each parameter of each sample. Hierarchical cluster analysis was used to enables the grouping of the samples or parameters without any previous classification (El-Nady and Lotfy, 2016) and these differences were squared. By adding the individual matrices, a summed matrix was obtained. In order that in the final matrix each parameter becomes an equal share, the values of the parameters were preliminarily standardized. Based on the final matrix, dendrograms were constructed following previously described methods (Golobocanin et al., 2004; Adamu et al., 2020). Also Pearson's correlation and Linear regression analyses were performed as described by El-Nady and Lotfy, (2016) and Adamu et al., (2020). 


\section{Adamu et al: Geochemical Evidence for the Origin of the Daranna Manganese Deposit...}

\section{RESULTS AND DISCUSSION}

\section{Correlation between Major, Trace Elements and Total Organic Carbon (TOC) of the Daranna Manganese Deposits}

The correlations among organic contents (Table 1), major and trace element concentrations (Table 2a and $b$ ) of ore samples are presented in Table 3, Figure 3 and Figure 4. Elements with similar geochemical behavior are discriminated in the correlation matrix dendogram (Figure 8). In this respect, three 3 different element groups were determined as $\left(\mathrm{MnO}, \mathrm{SiO}_{2}, \mathrm{LOI}, \mathrm{Al}_{2} \mathrm{O}_{3}\right.$, $\mathrm{Fe}_{2} \mathrm{O}_{3}, \mathrm{~K}_{2} \mathrm{O}, \mathrm{CaO}, \mathrm{MgO}, \mathrm{NiO}, \mathrm{ZnO}, \mathrm{TiO}_{2}, \mathrm{CuO}$, $\left.\mathrm{Na}_{2} \mathrm{O}, \mathrm{PbO}, \mathrm{V}_{2} \mathrm{O}_{3}\right),(\mathrm{Mn}, \mathrm{Pb}, \mathrm{Co}, \mathrm{Cu})$ and $(\mathrm{Zn}-\mathrm{Ni})$. In the formation of element groups, the similarities of correlation coefficients were taken into account. According to Choi and Hariya, (1992), Bonatti et al. (1972), Crerar et al., (1982), Roy et al., (1990) and Nicholson, (1992), positive correlations of $\mathrm{Zn}$ and $\mathrm{Ni}$ with $\mathrm{Mn}$ may give valuable information on the origin of the mineralization under investigation. Al and Ti have detrital characteristics, $\mathrm{Mn}$ and $\mathrm{Si}$ in association with $\mathrm{Pb}, \mathrm{Zn}$ and $\mathrm{Cu}$ are indicative of hydrothermal activity. The association of $\mathrm{Fe}_{2} \mathrm{O}_{3}$ with $\mathrm{Pb}$, which is one of the elements indicating the presence of hydrothermal activity. On the basis of Table 3,
$\mathrm{SiO}_{2}$ and $\mathrm{Fe}_{2} \mathrm{O}_{3}$ displays same negative correlations mainly with $\mathrm{MnO}$ and $\mathrm{V}_{2} \mathrm{O}_{3}$ and $\mathrm{Ni}$. Positive correlations of $\mathrm{Al}_{2} \mathrm{O}_{3}$ with $\mathrm{Zn}$ and $\mathrm{Ni}$ may show that these elements have a sedimentary origin. $\mathrm{MnO}$ shows negative correlation with $\mathrm{SiO}_{2}$, $\mathrm{Al}_{2} \mathrm{O}_{3}, \mathrm{Fe}_{2} \mathrm{O}_{3}$ and $\mathrm{TiO}_{2}$ that were determined to have a sedimentary origin. This could explain that manganese is derived from a hydrothermal source.

The present of organic carbon as total organic carbon (TOC) suggest influence of sedimentary processes. The negative correlation of organic carbon (TOC) with all the oxides and trace elements except $\mathrm{SiO}_{2}$ and $\mathrm{Pb}$ suggests influence of sedimentary processes. Major and trace element concentrations of manganese mineralization of various origins from Japan, Turkey and the study area (Nigeria) are compared and results presented in Table 3 . In comparison with sedimentary $\mathrm{Mn}-\mathrm{Fe}$ deposits, it is shown that concentrations of all other trace elements except for $\mathrm{Cr}$ and $\mathrm{Pb}$ are lower than those of the Daranna mineralization. All these data may imply that the Daranna mineralization might have formed via both hydrothermal and sedimentary processes.

Table 1: Total organic carbon content and rock-eval pyrolysis results of Daranna manganese deposit

\begin{tabular}{lllllll}
\hline PARAMETER & KB-1B & KB-1C & KB-2A & KB-3A & KB-4A1 & KB-4A2 \\
\hline TOC & 2.84 & 3.13 & 3.11 & 4.53 & 1.96 & 2.03 \\
S1 & 0.00 & 0.00 & 0.00 & 0.00 & 0.00 & 0.00 \\
S2 & 0.18 & 0.05 & 0.03 & 0.01 & 0.01 & 0.00 \\
S3 & 0.73 & 0.78 & 0.40 & 0.46 & 0.31 & 0.19 \\
HI & 6.00 & 2.00 & 1.00 & 0.00 & 1.00 & 0.00 \\
OI & 26.00 & 25.00 & 13.00 & 10.00 & 16.00 & 9.00 \\
\hline
\end{tabular}

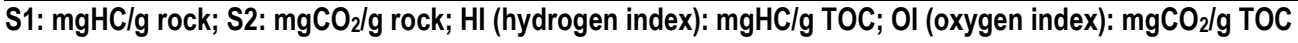


Nigerian Journal of Basic and Applied Science (December, 2021), 29(2):30-45

Table 2a: Major element content of Daranna manganese ore deposit (major elements in wt \%).

\begin{tabular}{|c|c|c|c|c|c|c|c|c|c|c|c|c|c|c|c|}
\hline $\begin{array}{l}\text { MAJOR } \\
\text { OXIDE } \\
\text { COMPOSITIO } \\
\mathrm{N}(\%)\end{array}$ & $\begin{array}{l}K B- \\
1 A\end{array}$ & $\begin{array}{l}\text { KB- } \\
1 A 1\end{array}$ & $\begin{array}{l}\text { KB- } \\
1 A 2\end{array}$ & $\begin{array}{l}\text { KB- } \\
\text { 2B }\end{array}$ & $\begin{array}{l}\text { KB- } \\
\text { 2B1 }\end{array}$ & $\begin{array}{l}\text { KB- } \\
\text { 2B2 }\end{array}$ & \begin{tabular}{|l} 
KB- \\
3B
\end{tabular} & $\begin{array}{l}\text { KB- } \\
\text { 3B1 }\end{array}$ & $\begin{array}{l}\text { KB- } \\
\text { 3B2 }\end{array}$ & \begin{tabular}{|l}
$K B-$ \\
$4 B$
\end{tabular} & $\begin{array}{l}\text { KB- } \\
\text { 4B1 }\end{array}$ & $\begin{array}{l}\text { KB- } \\
\text { 4B2 }\end{array}$ & MIN & MAX & $\begin{array}{l}\text { AVERAG } \\
\text { E }\end{array}$ \\
\hline SiO2 & 14.69 & 15.20 & 14.99 & 29.32 & 24.53 & $\begin{array}{l}19.9 \\
9 \\
\end{array}$ & 6.02 & $\begin{array}{l}8.02 \\
0 \\
\end{array}$ & 6.82 & \begin{tabular}{|l|}
41.6 \\
9 \\
\end{tabular} & $\begin{array}{l}38.9 \\
9 \\
\end{array}$ & 40.89 & 6.02 & \begin{tabular}{|l|}
41.6 \\
9 \\
\end{tabular} & 21.76 \\
\hline TiO2 & 0.09 & 0.09 & 0.10 & 0.12 & 0.11 & 0.12 & 0.07 & 0.07 & 0.06 & 0.15 & 0.16 & 0.15 & 0.06 & 0.16 & 0.11 \\
\hline Al2O3 & 11.6 & 12.11 & 10.80 & 12.02 & 11.99 & $\begin{array}{l}12.1 \\
2\end{array}$ & \begin{tabular}{|l|}
10.1 \\
3
\end{tabular} & $\begin{array}{l}10.7 \\
1\end{array}$ & $\begin{array}{l}10.6 \\
1\end{array}$ & \begin{tabular}{|l|}
12.0 \\
8
\end{tabular} & $\begin{array}{l}12.0 \\
1\end{array}$ & \begin{tabular}{|l|}
12.07 \\
\end{tabular} & 10.13 & $\begin{array}{l}12.1 \\
2\end{array}$ & 11.51 \\
\hline $\mathrm{Fe} 2 \mathrm{O} 3$ & 3.02 & 3.00 & 3.06 & 2.98 & 3.03 & 3.19 & 2.59 & 2.88 & 2.60 & \begin{tabular}{|l|}
3.21 \\
\end{tabular} & 3.31 & 3.22 & 2.59 & 3.31 & 3.00 \\
\hline $\mathrm{CaO}$ & 1.00 & 0.99 & 0.89 & 0.93 & 1.00 & 1.00 & 0.68 & 0.70 & 0.60 & 0.42 & 0.63 & 0.38 & 0.60 & 1.00 & 0.77 \\
\hline $\mathrm{MgO}$ & 0.33 & 0.40 & 0.26 & 0.11 & 0.22 & 0.21 & 0.53 & 0.41 & 0.39 & 0.09 & 0.13 & 0.09 & 0.09 & 0.53 & 0.26 \\
\hline $\mathrm{Na} 2 \mathrm{O}$ & 0.04 & 0.04 & 0.03 & 0.02 & 0.02 & 0.03 & 0.03 & 0.02 & 0.02 & 0.03 & 0.03 & 0.03 & 0.02 & 0.04 & 0.03 \\
\hline K2O & 0.92 & 0.89 & 0.90 & 0.68 & 0.77 & 0.69 & 0.91 & 0.78 & 0.86 & 0.34 & 0.50 & 0.47 & 0.34 & 0.92 & 0.72 \\
\hline MnO & 52.0 & 54.10 & 51.94 & 39.42 & 41.84 & $\begin{array}{l}45.6 \\
3 \\
\end{array}$ & \begin{tabular}{|l|}
62.3 \\
3 \\
\end{tabular} & $\begin{array}{l}60.8 \\
8 \\
\end{array}$ & \begin{tabular}{|l|}
61.6 \\
7 \\
\end{tabular} & \begin{tabular}{|l|}
26.8 \\
2 \\
\end{tabular} & $\begin{array}{l}27.6 \\
8 \\
\end{array}$ & 26.66 & 26.66 & \begin{tabular}{|l|}
62.3 \\
3 \\
\end{tabular} & 45.91 \\
\hline V203 & $\begin{array}{l}<0.00 \\
1\end{array}$ & $\begin{array}{l}<0.00 \\
1 \\
\end{array}$ & $\begin{array}{l}<0.00 \\
1 \\
\end{array}$ & \begin{tabular}{|l|}
$<0.00$ \\
1 \\
\end{tabular} & $\begin{array}{l}<0.00 \\
1\end{array}$ & $\begin{array}{l}0.00 \\
2 \\
\end{array}$ & \begin{tabular}{|l|}
0.00 \\
2 \\
\end{tabular} & $\begin{array}{l}0.00 \\
2 \\
\end{array}$ & \begin{tabular}{|l|}
0.00 \\
2 \\
\end{tabular} & ND & ND & \begin{tabular}{|l|}
$<0.00$ \\
1 \\
\end{tabular} & $\begin{array}{l}<0.00 \\
1 \\
\end{array}$ & $\begin{array}{l}0.00 \\
2 \\
\end{array}$ & 0.002 \\
\hline $\mathrm{Cr} 2 \mathrm{O} 3$ & ND & ND & ND & ND & $\mathrm{ND}$ & ND & ND & ND & ND & ND & ND & ND & ND & ND & ND \\
\hline CuO & 0.03 & 0.05 & 0.02 & 0.01 & 0.02 & 0.01 & 0.07 & 0.06 & 0.07 & 0.02 & 0.02 & 0.02 & 0.01 & 0.07 & 0.03 \\
\hline $\mathrm{ZnO}$ & 0.28 & 0.27 & 0.19 & 0.17 & 0.26 & 0.20 & 0.22 & 0.23 & 0.22 & 0.27 & 0.19 & 0.28 & 0.17 & 0.28 & 0.23 \\
\hline $\mathrm{PbO}$ & 0.002 & 0.002 & 0.001 & ND & ND & ND & 0.01 & $\begin{array}{l}0.00 \\
8 \\
\end{array}$ & 0.01 & ND & ND & ND & 0.001 & 0.01 & 0.006 \\
\hline $\mathrm{NiO}$ & 0.24 & 0.20 & 0.18 & 0.08 & 0.10 & 0.19 & 0.21 & 0.20 & 0.20 & 0.18 & 0.20 & 0.19 & 0.18 & 0.24 & 0.18 \\
\hline LOI & 15.30 & 12.50 & 16.40 & 13.90 & 15.70 & $\begin{array}{l}15.9 \\
8 \\
\end{array}$ & \begin{tabular}{|l|}
15.6 \\
0 \\
\end{tabular} & $\begin{array}{l}14.5 \\
0 \\
\end{array}$ & \begin{tabular}{|l|}
15.4 \\
0 \\
\end{tabular} & \begin{tabular}{|l|}
14.3 \\
0 \\
\end{tabular} & $\begin{array}{l}15.8 \\
0 \\
\end{array}$ & 15.20 & 12.50 & $\begin{array}{l}16.4 \\
0 \\
\end{array}$ & 15.04 \\
\hline Summation & 99.54 & 99.88 & 99.79 & 99.77 & 99.61 & $\begin{array}{l}99.4 \\
9 \\
\end{array}$ & \begin{tabular}{|l|}
99.4 \\
0 \\
\end{tabular} & $\begin{array}{l}99.5 \\
0 \\
\end{array}$ & \begin{tabular}{|l|}
99.5 \\
8 \\
\end{tabular} & \begin{tabular}{|l|}
99.6 \\
1 \\
\end{tabular} & $\begin{array}{l}99.6 \\
9 \\
\end{array}$ & 99.68 & 99.40 & $\begin{array}{l}99.8 \\
8 \\
\end{array}$ & 99.63 \\
\hline
\end{tabular}


Adamu et al: Geochemical Evidence for the Origin of the Daranna Manganese Deposit...

Table 2b: Trace element content of manganese ore deposit

\begin{tabular}{|c|c|c|c|c|c|c|c|c|c|c|c|c|c|c|c|}
\hline $\begin{array}{l}\text { E } \\
\text { ENTS }\end{array}$ & KB-1A & KB-1A1 & KB-1A2 & KB-2B & KB-2B1 & KB-2B2 & KB-3B & KB-3B1 & KB-3B2 & KB-4B & KB-4B1 & KB-4B2 & MIN & MAX & AVE \\
\hline & 249.87 & 427.19 & 193.44 & 73.01 & 153.32 & 532.97 & 581.86 & 534.03 & 573.88 & 167.68 & 231.55 & 159.69 & 73.01 & 581.86 & 323 \\
\hline & 2263.48 & 2239.40 & 1597.27 & 1413.46 & 2136.25 & 1662.42 & 1795.05 & 1907.74 & 1835.29 & 2210.98 & 1599.94 & 2251.18 & 1413.46 & 2263.48 & 15 \\
\hline & 18.41 & 18.41 & 9.20 & ND & ND & ND & 74.57 & 59.65 & 74.57 & ND & ND & ND & 9.20 & 74.57 & 42 \\
\hline & 40.28 & 41.82 & 40.20 & 30.51 & 32.38 & 35.31 & 48.24 & 47.11 & 47.72 & 20.76 & 21.42 & 20.63 & 21.42 & 48.24 & 35 \\
\hline & 1920.14 & 1589.62 & 1487.32 & 673.28 & 845.51 & 1550.11 & 1650.42 & 1595.40 & 1634.70 & 1428.14 & 1577.23 & 1490.91 & 673.28 & 1920.14 & 14 \\
\hline & 179.04 & 147.86 & 159.60 & 86.70 & 102.01 & 98.20 & 113.61 & 122.20 & 116.60 & 86.69 & 88.54 & 87.70 & 86.70 & 179.04 & 11 \\
\hline & ND & ND & ND & ND & ND & ND & ND & ND & ND & ND & ND & ND & ND & ND & ND \\
\hline nation & 4671.22 & 4464.31 & 3487.06 & 2276.96 & 3269.48 & 3878.82 & 4463.75 & 4266.16 & 4282.78 & 3914.25 & 3518.70 & 4010.12 & 2276.96 & 4671.22 & 38 \\
\hline $0+\mathrm{Ni}) \times 10$ & 23490.50 & 21646.81 & 18403.74 & 8329.90 & 11008.45 & 21812.83 & 23458.90 & 22518.40 & 23251.91 & 16825.10 & 18973.29 & 17383.10 & 8329.90 & 23490.50 & 18 \\
\hline $0+\mathrm{Ni}$ & 2349.05 & 2164.68 & 1840.37 & 832.99 & 1100.84 & 2181.28 & 2345.89 & 2251.84 & 2325.19 & 1682.51 & 1897.32 & 1738.31 & 832.99 & 2349.05 & \\
\hline & 0.07 & 0.06 & 0.10 & 0.06 & 0.04 & 0.05 & 0.06 & 0.06 & 0.06 & 0.03 & 0.05 & 0.03 & 0.03 & 0.10 & 0.0 \\
\hline & 17.23 & 18.03 & 16.97 & 13.22 & 13.80 & 14.27 & 24.06 & 21.13 & 23.71 & 8.35 & 8.36 & 8.27 & 8.27 & 24.06 & 15 \\
\hline & 0.09 & 0.09 & 0.10 & 0.12 & 0.11 & 0.06 & 0.06 & 0.07 & 0.07 & 0.06 & 0.05 & 0.05 & 0.05 & 0.12 & 0.0 \\
\hline
\end{tabular}




\section{Nigerian Journal of Basic and Applied Science (December, 2021), 29(2):30-45}

Table 3: Comparison of Daranna manganese occurrences with manganese ores from other locations

\begin{tabular}{|c|c|c|c|c|c|c|c|c|c|c|c|c|}
\hline $\begin{array}{l}\text { ORE } \\
\text { DEPOSIT }\end{array}$ & (1) & (2) & (3) & (4) & (5) & (6) & (7) & (8) & (9) & (10) & (11) & (12) \\
\hline Origins & & $\bar{A}$ & & & & $C$ & & & $\overline{A C}$ & & $\bar{A}$ & $\overline{A B}$ \\
\hline $\mathrm{SiO}_{2}$ & 25.87 & 63.02 & 43.69 & 13.6 & 10.65 & 12.67 & 9.41 & 16.04 & 84.39 & 49.62 & 44.09 & 21.76 \\
\hline $\mathrm{Al}_{2} \mathrm{O}_{3}$ & 1.07 & 0.65 & 0.73 & 2.49 & 2.85 & 1.27 & 12.53 & 0.73 & 1.29 & 3.66 & 0.80 & 11.52 \\
\hline $\mathrm{Fe}_{2} \mathrm{O}_{3}$ & 2.44 & 0.68 & 2.96 & 3.72 & 2.46 & 0.59 & 20.33 & 0.26 & 0.76 & 6.63 & 5.75 & 3.01 \\
\hline $\mathrm{MnO}$ & 45.59 & 29.22 & 45.88 & 63.78 & 33.39 & 67.21 & 33.78 & 69.91 & 8.82 & 26.79 & 42.46 & 45.92 \\
\hline $\mathrm{Na}_{2} \mathrm{O}$ & 0.12 & 0.05 & 0.29 & 0.24 & 0.39 & 0.07 & 0.07 & 0.01 & 0.17 & 0.18 & 0.30 & 0.03 \\
\hline $\mathrm{K}_{2} \mathrm{O}$ & 0.21 & 0.11 & 0.22 & 0.05 & 0.56 & 0.46 & 0.88 & 0.05 & 0.2 & 0.67 & 1.27 & 0.73 \\
\hline $\mathrm{P}_{2} \mathrm{O} 5$ & 0.08 & 0.04 & 0.25 & 0.18 & 0.31 & 0.12 & 3.73 & 0.07 & 0.02 & 0.11 & 0.13 & \\
\hline $\mathrm{Cr}$ & $(-)$ & 13.7 & 45 & $(-)$ & 26 & 16 & 247 & $(-)$ & $(-)$ & $(-)$ & 29.85 & $(-)$ \\
\hline Co & 28.75 & 25.21 & 11 & 13 & 59 & 222 & 404 & 103.5 & 85.36 & 367.4 & 125.24 & 115.73 \\
\hline $\mathrm{Mn} / \mathrm{Fe}$ & 56.23 & 97.17 & 199 & 18.98 & 15.03 & 133.43 & 2.16 & 880.33 & 18.85 & 6.06 & 105.37 & 15.62 \\
\hline Co/Zn & 0.38 & 0.38 & 0.17 & 0.19 & 1.2 & 1.51 & 0.7 & 2.24 & 2.2 & 4.49 & 0.57 & 0.06 \\
\hline Co/Ni & 0.33 & 0.36 & 0.31 & 1.3 & 0.35 & 0.65 & 1.32 & 1.54 & 0.99 & 1.31 & 0.51 & 0.08 \\
\hline
\end{tabular}

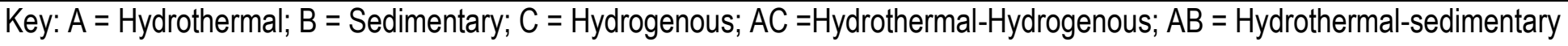

Iran (Dehoo (1), Nasirabad (9)); Turkey (Cayirli (2), Ulukent (4), Binkilic (5), Buyukmahal (10)); Pakistan (Wazirstan (3), Hazara (7), Zhob (11)); Japan (Honde (6)); Nigeria Daranna (12) 


\section{Adamu et al: Geochemical Evidence for the Origin of the Daranna Manganese Deposit...}

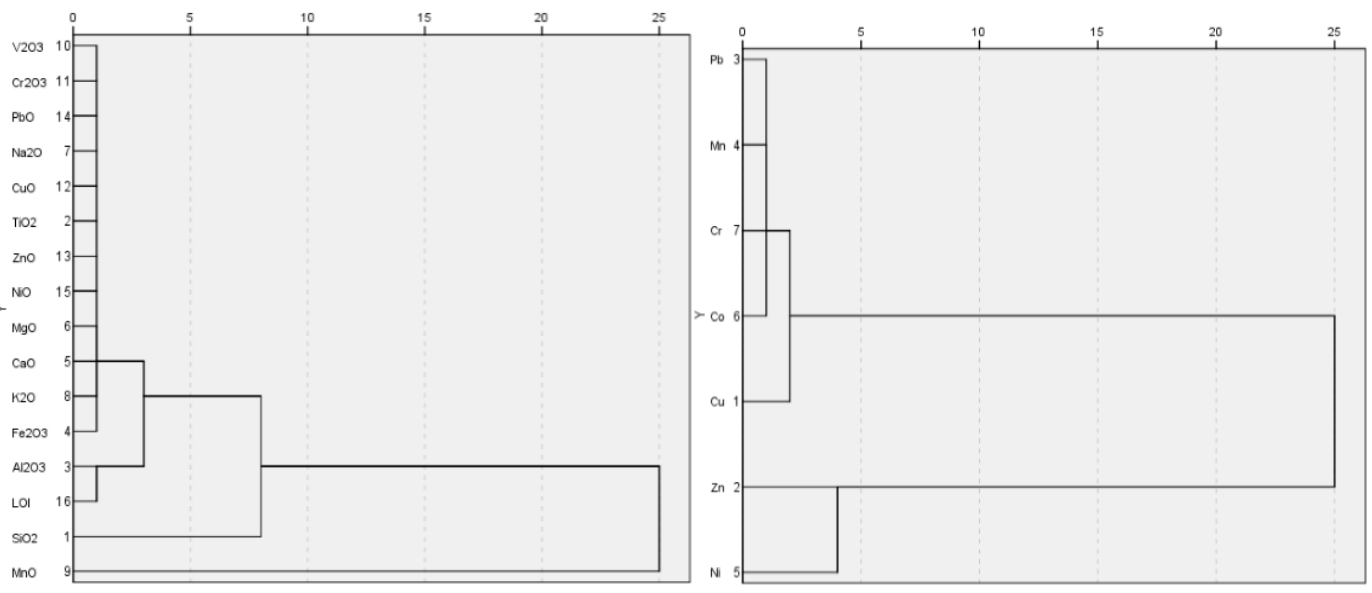

Figure 3. (a) Major element correlation matris dendogram of Daranna manganese ore samples, (b) Trace element correlation matris dendogram of Daranna manganese ore samples.

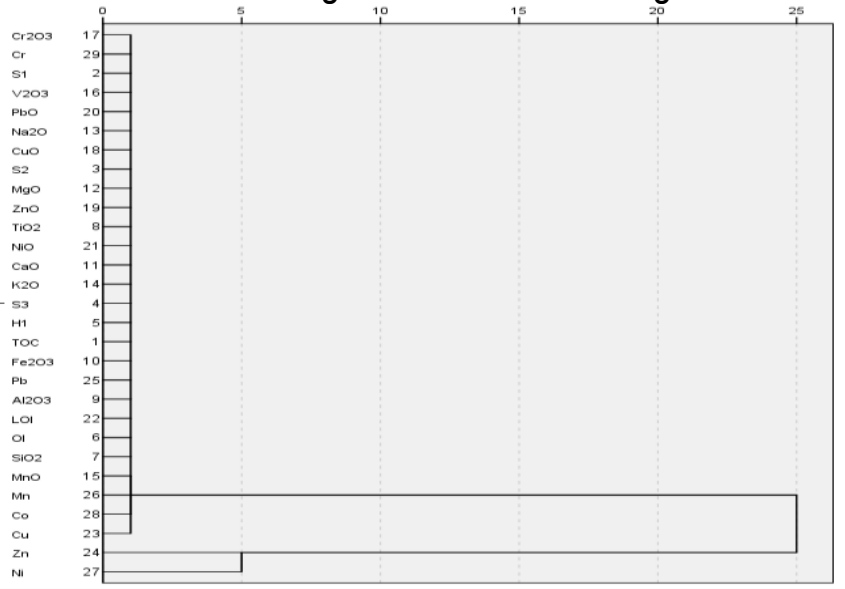

Figure 4: Major, trace element and TOC contents correlation matris dendogram of Daranna manganese ore samples

\section{Geochemical Characterization}

Chemical compositions of the Daranna Mn deposit are presented in Table 1. $\mathrm{MnO}, \mathrm{SiO}_{2}$, $\mathrm{Al}_{2} \mathrm{O}_{3}$ and $\mathrm{F}_{2} \mathrm{O}_{3}$ are the most abundant oxides in the Daranna Mn deposit. According to Karakus et al. (2010), in the domain with presiding hydrothermal processes, the $\mathrm{SiO}_{2}$ content is much higher than sedimentary formations. However, in addition to hydrothermal processes, other variables such as diagenetic components, clastic materials and biosilica presence can grow the Si values (Toth, 1980; Polgari et al., 2012). $\mathrm{MnO}$ content of ore samples from Daranna is considerably very high (26.660-62.330 wt \%).

The $\mathrm{SiO}_{2}$ content ranges from 6.020 to $41.690 \mathrm{wt}$ $\%$ in ore samples in Daranna Mn deposit. In the
Daranna $\mathrm{Mn}$ deposit, the $\mathrm{F}_{2} \mathrm{O}_{3}$ content ranges from 2.590 to $3.310 \mathrm{wt} \%$ (Table 1). Mn/Fe ratios according to Hein et al., 1997 is generally controlled by initial ratios in liquid, hydrothermal discharging distance and Eh-pH conditions (Roy, 1992) of the depositional environment, so that the solution of $\mathrm{Mn}$ in a wide range of $\mathrm{Eh}-\mathrm{pH}$ conditions can separate $\mathrm{Mn}$ from $\mathrm{Fe}$ and cause a variation in $\mathrm{Mn} / \mathrm{Fe}$ ratios. Consequently, $\mathrm{Mn} / \mathrm{Fe}$ ratios are anticipated to differ in different environments of deposition. $\mathrm{Mn} / \mathrm{Fe}$ ratios in the Daranna Mn deposit range from 8.274 to 24.066 , which according to Hein et al. (1996) and Hein et al. (1994), is a leading characteristic of hydrothermal manganese deposits. Submarine exhalative activities (Roy, 1992), are the most 


\section{Nigerian Journal of Basic and Applied Science (December, 2021), 29(2):30-45}

important suppliers of Si that generally precipitate as ferrigenous gel. These deposits according to Peters, (1988) are also enriched in Fe relative to $\mathrm{Al}$, whereas detrital sources are more enriched in Al relative to $\mathrm{Si}$ of which is tied to the decomposition and destruction of feldspars during transportation. The $\mathrm{Al}_{2} \mathrm{O}_{3}$ contents of the Daranna $\mathrm{Mn}$ deposit present in ore samples varies from $10.130-12.120$ wt \%, averaging 11.518 wt \%. According to the works of Sugisaki et al. (1982) and Kato et al. (2002); Kato and Nakamura (2003), the $\mathrm{Al}_{2} \mathrm{O}_{3}-\mathrm{TiO}_{2}$ diagram is widely used to estimate a source of detrital material in sedimentary rocks which Brookins, (1988) attributed to be due to the fact that Ti and $\mathrm{Al}$ are generally insoluble in natural waters. Sabatino et al. (2011) reported Co to be strongly associated with $\mathrm{Mn}$ oxides and concluded that its abundance is reduced on average from hydrogenetic to diagenetic to hydrothermal oxide deposits. Microbial metabolic processes according to Moffett and Ho (1996) and Polgári et al. (2012) can increase Co and $\mathrm{Mn}$ concentrations in manganese deposits.

According to Toth, (1980), hydrothermal and hydrogenetic manganese deposits have mean Co/Zn ratios of 0.15 and 2.5 , respectively. He used Co/Zn ratio to delineate hydrothermal and hydrogenous deposits; hydrothermal and hydrogenous manganese deposits having mean Co/Zn ratio of 0.15 and 2.5 , respectively. In the Daranna Mn deposit the average ratio of Co/Zn is 0.061 , similar to that of hydrothermal manganese deposits. Behavior of $\mathrm{Co}$ is closely related with $\mathrm{Ni}$ (Toth, 1980). According to (Toth, 1980), the $\mathrm{Co} / \mathrm{Ni}$ ratio is an important criterion for determination of sedimentary environment particularly hot water sedimentation on the sea floor which he concluded it to being used to distinguish hydrogenous and hydrothermal deposits. Co/Ni < 1 according to Fernandez and Moro (1998) is indicative of sedimentary origin while Co/Ni > 1 according to Delian, (1994) represents for a deep marine environment. A combination of $\mathrm{Co} / \mathrm{Ni}$ and $\mathrm{Co} / \mathrm{Zn}$ ratios is proposed as $\mathrm{Ni}-\mathrm{Zn}-\mathrm{Co}$ ternary diagram by Choi and Hariya (1992) in sight to discriminate of dissimilar marine deposits within numerous geneses. In Ni-Zn-Co ternary diagram, the Daranna $\mathrm{Mn}$ ore samples overlap the hydrothermal field (Figure 5a). Nicholson, (1992) reveal that hydrothermal veins and their weathered oxide cappings exhibit upraised levels of target and pathfinder elements.

The association $\mathrm{Cu}-\mathrm{Pb}-\mathrm{Zn}$ is consistently enriched where all or most of the elements in the association consistently attain a concentration from the mid-hundreds to thousands of ppm) and is considered to be part of the diagnostic hydrothermal assemblage (Nicholson, 1992). Marine manganese oxides occurring as hydrogenous crusts, coatings and nodules display enrichments in $\mathrm{Na}-\mathrm{K}-\mathrm{Ca}-\mathrm{Mg}-\mathrm{Sr}$ (all major components of seawater) and those formed in the deep oceanic environment are also enriched in Co-Cu-Ni. Thus, samples from the Daranna $\mathrm{Mn}$ deposit are enriched in $\mathrm{Co}-\mathrm{Cu}-\mathrm{Ni}$ hydrothermal area of deep oceanic environment. According to Bonatti et al. (1972), hydrothermal $\mathrm{Mn}$ oxides exhibit higher depletion in $\mathrm{Cu}, \mathrm{Ni}, \mathrm{Co}$ and $\mathrm{Zn}$ than hydrogenetic deposits. This is due to the long presence of hydrogenetic deposits in sea water that causes enrichment of $\mathrm{Zn}, \mathrm{Co}, \mathrm{Ni}$ and $\mathrm{Cu}$ by cation adsorption of hydrous iron and manganese oxides (Toth, 1980; Usui and Someta, 1997). The oxidized forms of $\mathrm{Mn}$ are very reactive and have a strong adsorption capacity for cationic species (Anschutz et al., 2005); hence, trace metal characteristics of manganese deposits are strongly dependent on the concentration of manganese oxides according to Nicholson, (1992). The Co/Zn vs. $\mathrm{Co}+\mathrm{Ni}+\mathrm{Cu}$ diagram (Toth, 1980), reveals $(80 \%)$ diagenetic genesis with hydrothermal processes for the Daranna deposits (Figure 5b). 


\section{Adamu et al: Geochemical Evidence for the Origin of the Daranna Manganese Deposit...}
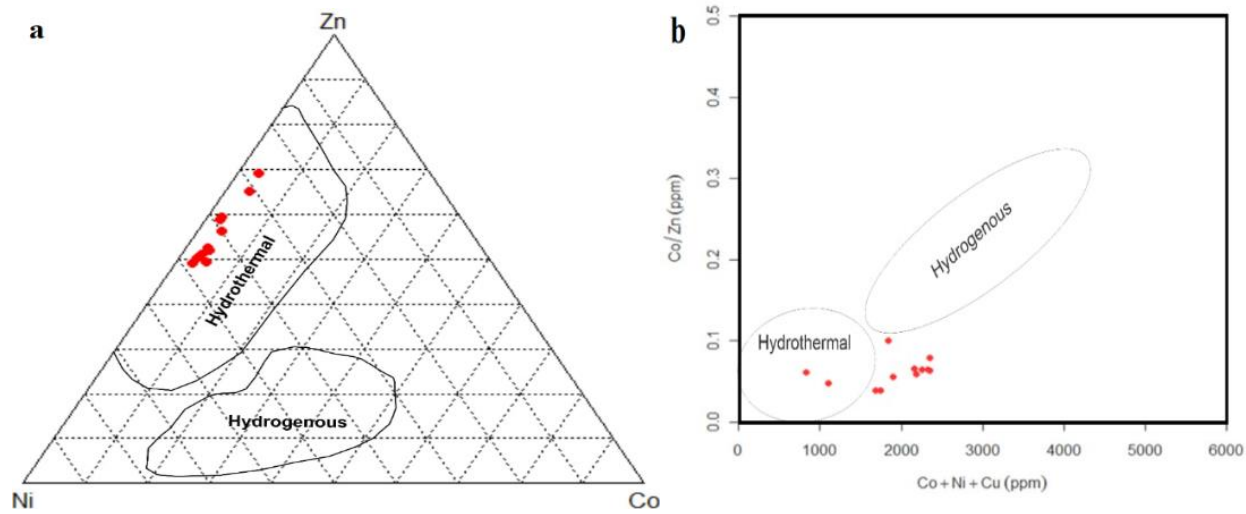

Figure 5: (a) The Daranna Mn deposit on the Ni-Zn-Co ternary diagram (Choi and Hariya, 1992) (b) A plot of $(\mathrm{Co} / \mathrm{Zn})$ vs. $(\mathrm{Co}+\mathrm{Na}+\mathrm{Cu})$ for the manganese ores of Daranna Mn deposit (after Toth, 1980).
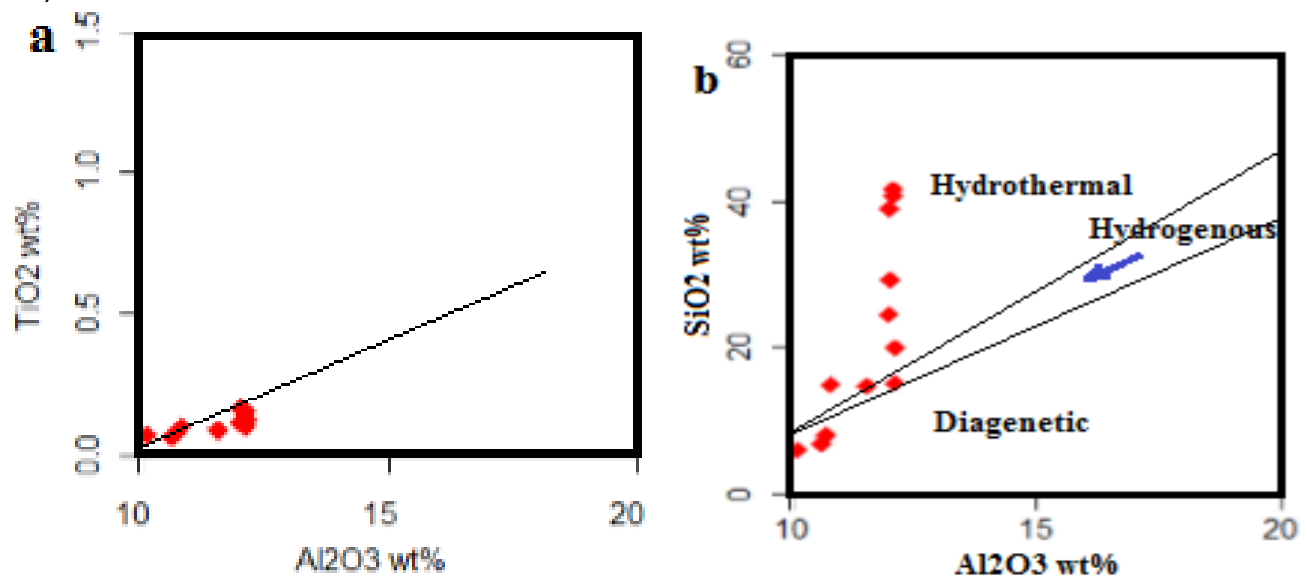

Figure 6: (a) TiO2 vs. Al2O3 diagrams of Daranna manganese ore samples. (b) Bivariate plot of $\mathrm{SiO} 2$ vs. Al2O3 (Choi and Hariya, 1992) in which majority $(50 \%)$ of the data points of the ore samples fall within the hydrothermal field while $30 \%$ and $20 \%$ fall within diagenetic and hydrogenous field respectively.

Major element contents of ore samples are given in Table 1. Fe, Mn, Al, Si and Ti concentrations are helpful for evaluations of the origin. Carliss et al. (1978), Nicholson (1992), Choi and Hariya (1992) demonstrated that, hydrothermal deposits associated with the active ocean spreading centers display low Fe/Mn ratios. According to Nicholson (1992), Fe-Mn concentrations in exhalative sedimentary deposits vary in a wide range $(0.1<\mathrm{Fe} / \mathrm{Mn}<10)$ reflecting a strong Fe$\mathrm{Mn}$ fractionation and this ratio in hydrogenetic deposits is around 1. Fe/Mn ratios of samples from the study area change in a wide interval (8.274- 24.066). Such a range indicates that mineralization is not hydrogenetic but could be a hydrothermal type. In their detailed geochemical study on the Tokoro manganese oxide deposits in Japan, Choi and Hariya, (1992) described the deposit as the hydrothermal type and found the Fe/Mn ratio to be $0.017-6.41$.

Submarine hydrothermal manganese deposits have low Fe/Mn ratios. In early stages of deposition, Fe/Mn ratios are higher (Bonatti et al., 1972). Fe-Mn deposits are generally formed around the center of active submarine hydrothermal sites while manganese oxide deposits are mostly developed in distal parts of the center (Choi and Hariya, 1992; Lalou, 1983). Like Fe and Mn, Al and Ti contents could also be used to evaluate the origin of mineralization. These two elements are abundantly found in sedimentary formations. High Al and Ti contents 


\section{Nigerian Journal of Basic and Applied Science (December, 2021), 29(2):30-45}

may indicate the sedimentary contribution to mineralization (Nicholson, 1992; Choi and Hariya, 1992; Bonatti et al., 1972; Crerar et al., 1980; Roy et al., 1990). For sedimentary Fe-Mn deposits in Table 3, the average $\mathrm{Al}$ and $\mathrm{Ti}$ concentrations are taken as $8.82 \%$ and $0.91 \%$, respectively. In Daranna mineralizations under investigation, Al concentrations are 10.130 . $12.120 \%$ (average is $11.518 \%$ ) and $\mathrm{Ti}$ concentrations are $0.067-0.166 \%$ (average is $0.111 \%)$ and these values indicate a sedimentary contribution to the mineralization (Table 1 and 4). It was stated in previous works (Crerar et al., 1980; Sugisaki, 1984) that Al and Ti display similar behavior during the mineralization. This relation is clearly shown in Figure 6a. The contents of $\mathrm{Al}$ and $\mathrm{Ti}$ in the Daranna deposits show a positive correlation (Figure 6a). This high positive correlation, therefore, supports the contribution of detrital material in the formation of the deposits. In Mn mineralization forming in volcanically active regions and in areas where hydrothermal processes are dominant (Table 3), $\mathrm{Si}$ content was found to be higher than in sedimentary formations (Nicholson, 1992). Si-Al diagram (Toth, 1980) which was constructed on the basis of $\mathrm{Al}$ and $\mathrm{Si}$ contents that represent sedimentary and hydrothermal sources, respectively, indicates that mineralization has a sedimentary origin (Figure 6b). Almost all the samples from the Daranna deposits plot within the field of hydrothermal deposits similar to the Waziristan (Pakistan) and Cayirli (Turkey) manganese deposits (Figure 6b). In addition to the hydrothermal processes, other processes and components such as diagenesis, clastic materials, and biosilica can increase the $\mathrm{Si}$ concentrations (Polgári et al., 2012; Toth, 1980).

The Daranna Mn deposit shows high enrichment in $\mathrm{Cu}, \mathrm{Zn}, \mathrm{Ni}$ and $\mathrm{Co}$ by an order of magnitude. Also a distinctive depletion of $\mathrm{Cr}$ content occurs in all samples. Average concentrations of $\mathrm{Cu}, \mathrm{Zn}$, $\mathrm{Ni}$ and $\mathrm{Co}$ are 108, 160, 125 and 50 ppm, respectively. These contents of $\mathrm{Cu}, \mathrm{Ni}$ and $\mathrm{Co}$ are relatively low compared with hydrogenetic deposits and are a characteristic of hydrothermal ferromanganese deposits (Heshmatbehzadi and
Shahabpour, 2010). Comparison of some major elements of the Daranna ore samples with various fields given in Table 3 reveals an origin somewhat close to hydrothermal and sedimentary formations. Particularly, $\mathrm{SiO}_{2}, \mathrm{TiO}_{2}$, $\mathrm{MgO}, \mathrm{CaO}, \mathrm{Al}_{2} \mathrm{O}_{3}, \mathrm{~K}_{2} \mathrm{O}$ and $\mathrm{Fe}_{2} \mathrm{O}_{3}$ values resemble submarine hydrothermal and sedimentary mineralizations in the Dehoo, Ukukent, Hazara, Wazirstan, Cayirli, Buyukmahal and Zhob regions classified by Choi and Hariya (1992). The difference between deep marine $\mathrm{Mn}$ nodules and submarine hydrothermal deposits was explained by various workers (Nicholson, 1992; Choi and Hariya, 1992; Crerar et al., 1980) with the use of $\mathrm{Zn}-\mathrm{Co}-\mathrm{Ni}$ triangular diagram. Concentrations of $\mathrm{Co}, \mathrm{Ni}, \mathrm{Cu}$ and $\mathrm{Zn}$ in hydrothermal $\mathrm{Mn}-\mathrm{Fe}$ deposits are high than pelagic sediments but lower than those of hydrogenetic deposits (Cronan, 1980). Among these elements, $\mathrm{Cu}, \mathrm{Ni}$ and $\mathrm{Zn}$ are indicative of hydrothermal formations while Co indicates hydrogenetic deposits (Crerar et al., 1980). Results of trace element analyses for the Daranna ore samples are given in Table 3. Zn$\mathrm{Ni}-\mathrm{Co}$ triangular diagram for the same samples is shown in Figure 5a. In this respect, since the distribution of samples away from the Co corner, it can be said that mineralization has a hydrothermal origin.

\section{CONCLUSION}

The geochemical and geostatistical studies of the manganese ore deposits in Daranna, near Kaoje area has been studied and from the results acquired from the analyses, it was concluded that the major and trace element signatures show that hydrothermal processes were responsible for the formation of mineralization at Daranna with a minor contribution from sedimentary deterital materials. Major, trace elements and total organic carbon content abundances and correlation among them imply that Daranna mineralizations are mainly of hydrothermal origin. The high $\mathrm{Fe} / \mathrm{Mn}$ and low Co/Zn ratios and trace element patterns, the absence of sulfide minerals coupled with relative enrichment of some bioessential elements such as Co, suggest that the Daranna 


\section{Adamu et al: Geochemical Evidence for the Origin of the Daranna Manganese Deposit...}

manganese deposits are hydrothermal in origin with sedimentary influence.

\section{ACKNOWLEDGEMENTS}

Acknowledgments go to Prof. N. G. Obaje for his contributions and the Nigerian National Petroleum Corporation (NNPC) Chair in Basinal Studies, Ibrahim Badamasi Babangida University, Lapai,

\section{CONFLICT OF INTERESTS}

The authors declare that there is no conflict of interests regarding the publication of this paper.

\section{REFERENCES}

Adamu, L. M., Obaje, N. G., Okafor, P. N., \& Umar, M. U. (2020). Integrated Geochemical and Multivariate Statistical Examination of Source Rocks in the Sokoto and Anambra Basins, Nigeria: Implications for Hydrocarbon Prospectivity, Petroleum Science and Engineering, 4(2):39-50.

Ajibade, A.C., Woakes, M., \& Rahaman, M. A. (1987). Proterozoic crustal development in the Pan-African regime of Nigeria. In:

A. Krooner (Editor), Proterozoic crustal evolution Geodynamic Services American Geophysics union, 17: 259 271.

Anschutz, P., Dedieu, K., Desmazes, F., \& Chaillou, G. (2005). Speciation, oxidation state, and reactivity of particulate manganese in marine sediments. Chemical Geology, 218, 265-279.

Bar, P. \& Mucke, A. (1982). Mineralisation and genesis einiger Nigerian ischer manganv rkornrncn (Tudun Kudu Hill,Ungwan Malam Ayuba, bei Gangara, Ruwan Doruwa and Maraba Hill). Fortschr. 1: $148-149$.

Bafor, B. E., \& and Mucke, A. (1990). The genesis of manganese concretions in the Igarra area, Southwestern Nigeria. Journal of African Earth Sciences, 10:595 - 601.

Binta, H. (2013). Upgrading of Wasagu manganese ore to metallurgical grade concentrate, Unpublished M.Sc Thesis, Ahmadu Bello University, Zaria, p 66.

Binta, H., Yaro, S.A., Thomas, D.G., \& Dodo, M.R. (2016). Beneficiation of low grade mangansese ore from Wasagu, Journal of Raw Materials and Development, 10(2): 45-51.

Bolton, B. R., Both, R., \& Exon, N. F. (1988). Geochemistry and Mineralogy of Seafloor Hydrothermal and Hydrogenetic $\mathrm{Mn}$ Oxide Deposits from the Manus Basin and Bismarck Archipelago Region of the Southwest Pacific Ocean. Marine Geology, 85(1): 65-87.

Bonatti, E., Kraemer, T., \& Rydell, H. (1972). Classification and Genesis of Submarine Iron-Manganese Deposits. In: Horn, D. R., ed., Ferromanganese Deposits of the Ocean Floor. National Science Foundation, Washington, DC. 149-166

Bonatti, E., Zerbi, M., \& Kay, R. (1976). Metalliferous Deposits from the Apennine Ophiolites: Mesozoic Equivalents of Modern Deposits from Oceanic Spreading Centers. Geological Society of America Bulletin, 87(1): 83-94.

Brookins, D. G. (1988). Eh-pH Diagrams for Geochemistry (Springer-Verlag, Berlin), pp. 60-63.

Caby, R. (1989). Precambrian terranes of BeninNigeria and Northeast Brazil and the Late Proterozoic South Atlantic fit, American Spectrum Paper, 230: 145 158.

Choi, J. H., \& Hariya, Y., (1992). Geochemistry and Depositional Environment of $\mathrm{Mn}$ Oxide Deposits in the Tokoro Belt, Northeastern Hokkaido, Japan. Economic Geology, 87(5): 1265-1274.

Crerar, D. A., Namson, J., \& Chyi, M. S. (1982). Manganiferous Cherts of the Franciscan Assemblage; I, General Geology, Ancient and Modern Analogues, and Implications for Hydrothermal Convection at Oceanic Spreading Centers. Economic Geology, 77(3): 519-540. 


\section{Nigerian Journal of Basic and Applied Science (December, 2021), 29(2):30-45}

Crerar, D. A., Cormick, R. K., \& Barnes, H. L. (1980). "Geochemistry of Manganese: An Overview," in Geology and Geochemistry of Manganese, Ed. by I. M. Varentsov and G. Graselly, (Hung. Acad. Sci., Budapest, 1980), 1: 293-334.

Cronan, D. S. (1980). Metallogenesis at oceanic spreading centers introduction. Journal of Geological Society, 137: 369-371

Dada, S. S., Birck, J. L., \& Rahaman, M. A. (1989). Archean Migmatite - Gneiss Complex of North-central Nigeria: Its geochemistry and evolution. International colloquium on African Geology, Mbabane Swaziland, 1: 97-102.

Delian, F. (1994). Geological and Geochemical Research of the Manganese Ore Bed (Weather Publishing Press, Beijing) (in Chinese).

El-Nady, M. M., \& Lotfy, N. M. (2016). Multivariate geochemical and statistical methods applied to assessment of organic matter potentiality and its correlation with hydrocarbon maturity parameters (Case study: Safir-1x well, North Western Desert Egypt): Egyptian Journal of Petroleum, 25: 97-105.

Fernandez, A. and Moro, M. C., (1998) Origin and depositional environment of Ordovician stratiform iron mineralization from Zamora (NW Iberian Peninsula). Mineralium Deposita, 33: 606-619.

Goloboc`anin, D. D., S`krbic', B. D. \& Miljevic', N. R. (2004): Principal component analysis for soil contamination with PAHs: Chemometrics Intelligent Laboratory Systems, 72: 219-223.

Hein, J. R., Gibbs, A. E., \& Clague, D. A. (1996). Hydrothermal Mineralization along Submarine Rift Zones, Hawaii. Marine Georesources \& Geotechnology, 14(2): 177-203.

Hein, J. R., Hsueh-Wen, Y., \& Gunn, S. H. (1994). Composition and Origin of Hydrothermal Ironstones from Central Pacific Seamounts. Geochimica et Cosmochimica Acta, 58(1): 179-189.
Hein, J. R., Koschinsky, A., \& Halbach, P. (1997). Iron and Manganese Oxide Mineralization in the Pacific. In: Nicholson, K., Hein, J. R., Buhn, B., et al., eds., Manganese Mineralization: Geochemistry and Mineralogy of Terrestrial and Marine Deposits. Geological Society Special Publication, 1997: 123-138.

Heshmatbehzadi, K., \& Shahabpour, J. (2010). "Metallogeny of manganese and ferromanganese ores in baft ophiolitic Melange, Kerman, Iran," Australian Journal of Basic and Applied Science, 4(2): 302-313.

Karakus, A., Yavuz, B. and Koc, S., 2010Mineralogy and major trace element geochemistry of the haymana manganese mineralizations, Ankara, Turkey. Geochemistry International, 48: 1014-1027.

Kato, Y., \& Nakamura, K. (2003). Origin and global tectonic significance of Early Archean cherts from the Marble Bar greenstone belt, Pilbara Craton, Western Australia, Precambrian Research, 125(3): 191-243.

Kato, Y., Nakao, K., \& Isozaki, Y. (2002). Geochemistry of Late Permian to Early Triassic pelagic cherts from southwest Japan: implications for an oceanic redox change, Chem. Geol., 182(1): 15-34.

McCurry, P., \& Wright J.B. (1977). Geochemistry of calc-alkaline volcanics in northwestern Nigeria, and a possible Pan- African suture zone. Geochemistry of calcalkaline volıcanics in northwestern Nigeria, and a possible Pan- African, 37: 90-6.

McCurry, P. (1970). The geology of Sheet 21, Zaria Unpublished M.Sc thesis, Ahmadu Bello University, Zaria.

Moffett, J. W., \& Ho, J. (1996). Oxidation of cobalt and manganese in seawater via a common microbially catalyzed pathway, Geochimica et Cosmochimica Acta, 60(18): 3415-3424. 


\section{Adamu et al: Geochemical Evidence for the Origin of the Daranna Manganese Deposit...}

Moneme, P. C., \& Scott, P. W. (1983). The mineralogy of Malam Ayuba manganese mineralization in Maska, Sheet (101). Nigerian Mining Geosciences Society 19th Annual Conference, Warri. pp. 23 24.

Moneme, P. C., Scott, P. W., \& Dunham, A. C. (1982). Occurrence of manganese ores in Zaria Area, Kaduna State. Nigerian Mining Geosciences Society Abstracts, 18th Annual Conference, Kaduna. pp. 17-18.

Mucke, A. (2005). The Nigerian manganese-rich iron formation and their host rocks- from sedimentation to metamorphism, Journal of Africa Earth Sciences, 41: 407 - 436.

Mucke, A., \& Okujeni, C. (1984). Geological and ore microscopic evidence on the epigenetic origin of the manganese occurrences in Northern Nigeria. Journal of Africa Earth Sciences, 3: 209 - 225.

Mücke, A., Dzigbodi-Adjimah, K., Annor, A., (1999). Mineralogy, Petrography, Geochemistry and Genesis of the Paleoproterozoic Birimian ManganeseFormation of Nsuta/Ghana. Mineralium Deposita, 34(3): 297-311.

Muriana, R. A. (2016). Discharge evaluation of battery-active chemical manganese dioxide produced from Madaka (Nigeria) manganese ore. Journal of Engineering Research, 20: 67-78.

Muriana, R. A., Muzenda. E., \& Abubakre, O. K. (2014). Extraction and production kinetics of industrial - grade manganese sulphate crystal from manganese. Journal of Engineering Research, 19: 78 -90 .

Nicholson, K. (1992). Contrasting MineralogicalGeochemical Signatures of Manganese Oxides; Guides to Metallogenesis. Economic Geology, 87(5): 1253-1264.

Norrish, K. and Hutton, J.T. (1969). An accurate $X$-ray spectrography method for the analysis of a wide range of geological samples, Geochim. Cosmochim. Acta 33 (1969): 431-453.
NSRMEA. (2010). National Steel Raw Materials Exploration Agency, geological report on manganese deposit in Kaoje, Bungudu, 3: $45-58$.

Obaje, N. G. (2009). Geology and Mineral Resources of Nigeria: Springer, Heildelberg, p 221.

Odeyemi, I. B. (1977). Late -Proterozonic metconglomerates in the Schist Belt of Nigeria: origin and tectonostratigraphic significance revisited. Journal of technoscience, 3:48-55.

Öksüz, N. (2011). Geochemical characteristics of the Eymir (Sorgun-Yozgat) manganese deposits. Journal of Rare Earths, 29(3): 287-296.

Oyinloye, A.O. (2006). Geology and geochemistry of some crystalline basement rocks in llesha area Sourthwestern Nigeria: Implications on provenance and evolution. Journal of Science India Research, 50: 223-231.

Peters, T. (1988). Geochemistry of manganesebearing cherts associated with Alpine ophiolites and the Hawasina formations in Oman. Marine Geology, 84(3-4): 229238.

Polgári, M., Hein, J. R., Vigh, T., Szabó-Drubina, M., Fórizs, I., Bíró, L., Müller, A. and Tóth, A. L., (2012). Microbial processes and the origin of the Úrkút manganese deposit, Hungary. Ore Geology Reviews, 47: 87- 109.

Raeburn, C. (1927). Tinstone in Calabar. Bulletin of Geological Survey of Nigeria, 11: 7288.

RMRDC. (2009). Non Metallic in Nigeria: Raw Material Research and Development Councils, Abuja, p 13.

Roy, S. (1992). Environments and Processes of Manganese Deposition. Economic Geology, 87(5): 1218-1236.

Roy, S., Bandopadhyay, P. C., \& Perseil, E. A. (1990). Late Diagenetic Changes in Manganese Ores of the Upper Proterozoic Penganga Group, India. Ore Geology Reviews, 5(4): 341-357. 


\section{Nigerian Journal of Basic and Applied Science (December, 2021), 29(2):30-45}

Sabatino, N., Neri, R., \& Bellanca, A. (2011). Petrography and High-Resolution Geochemical Records of Lower Jurassic Manganese-Rich Deposits from Monte Mangart, Julian Alps. Palaeogeography, Palaeoclimatology, Palaeoecology, 299(1/2): 97-109.

Sugisaki, R., Yamamoto, K., \&Adachi, M. (1982). Triassic bedded cherts in central Japan are not pelagic, Nature, 298(12): 644647.

Sugisaki, R. (1984). Relation between Chemical Composition and Sedimentation Rate of Pacific Ocean-Floor Sediments Deposited since the Middle Cretaceous: Basic Evidence for Chemical Constraints on Depositional Environments of Ancient Sediments. The Journal of Geology, 92(3): 235-259.

Toth, J. R. (1980). Deposition of Submarine Crusts Rich in Manganese and Iron. Geological Society of America Bulletin, 91(1), 44-54.

Truswell, J. F., \& Cope, R.N. (1963). The geology of parts of Niger and Zaria provinces, northern Nigeria. Bulletin of Geological Survey Nigeria, 29: $34-48$.

Usui, A., \& Someya, M. (1997). Distribution and Composition of Marine Hydrogenetic and Hydrothermal Manganese Deposits in the Northwest Pacific. Geological Society, London, Special Publications, 119(1): 177-198.

Woakes, M., Ajibade C.A., \& Rahaman, M.A. (1987). Some metallogenic features of the Nigerian Basement Complex, Journal of Africa Science, 5: 655-666.

Wright, J. B., \& McCurry, P. (1977). First occurrence of manganese ores in northern Nigeria. Economic Geology, 65: $103-106$.

Wright, J. B., \& McCurry, P. (1970). The geology of Nigeria Sheet 102 SW, Zaria and its regions. Edited by M. J. Mortimore. Department of Geography, Occasional paper, No. 4, Ahmadu Bello University, Zaria.

Yaro, S. A. (1998). Development of a process route for the beneficiation of Mallam Ayuba manganese deposit to ferromanganese feed grade. Unpublished Ph.D. Thesis, Ahmadu Bello University, Zaria, p 79.

Yaro, S.A. (1996): Grindability Test for Ririwai Lead -Zinc ore complex, Nigeria Mining Journal, 1(1): 117-4307

Zhang, T. P., Zhang, Y. C., \& Cai, K. Z. (2007): SPSS Statistic Modeling and Analytic Procedure: Kings Information Co., Ltd., Taipei, p 674. 